\title{
Evidences of Validity of the Difficulties in Emotion Regulation Scale - DERS
}

\author{
Bruna Mattos Machado ${ }^{1}$ \\ Léia Gonçalves Gurgel ${ }^{2}$ \\ Mariana Gonçalves Boeckel ${ }^{2}$ \\ Caroline Tozzi Reppold ${ }^{2}$
}

\begin{abstract}
Emotional regulation is a recent construct with few adapted instruments in Brazil capable of measuring it. This study aimed to find evidences of content validity, internal consistency and reliability of the Difficulties in Emotion Regulation Scale (DERS) for the Brazilian context. The participants were 402 adults ( $78.1 \%$ women) aged between 18 to 71 years, of which $86.8 \%$ resided in Rio Grande do Sul. We revised an adaptation of the referred instrument to facilitate the understanding of the items. In order to test the most appropriate structure to the Brazilian context, we performed a confirmatory factor analysis, comparing the original instrument structure to that validated to Portuguese. The results showed that DERS had good psychometric properties, exhibiting validity and reliability for the Brazilian sample. The factorial structure was equivalent to the original version, containing six dimensions.
\end{abstract}

Keywords: emotional regulation, psychological assessment, psychometry

\section{Evidências de Validade da Escala de Dificuldades de Regulação Emocional - DERS}

Resumo: A regulação emocional é um construto recente com poucos instrumentos adaptados no Brasil capazes de mensurá-la. Este estudo teve por objetivo buscar evidências de validade de conteúdo, consistência interna e fidedignidade da Escala de Dificuldades de Regulação Emocional (DERS) para o contexto brasileiro. Os participantes foram 402 adultos (78,1\% mulheres), com idade entre 18 e 71 anos, sendo 86,8\% residentes do Rio Grande do Sul. Para isso, revisou-se uma adaptação do referido instrumento com a finalidade de facilitar a compreensão dos itens. A fim de testar a estrutura mais adequada ao contexto brasileiro, realizou-se uma análise fatorial confirmatória, comparando-se a estrutura do instrumento original com outro validado para o contexto português. Os resultados apontaram que a DERS apresentou boas propriedades psicométricas, com evidências de validade e fidedignidade do instrumento para a amostra brasileira. A estrutura fatorial foi equivalente à da versão original, com seis dimensões.

Palavras-chave: regulação emocional, avaliação psicológica, psicometria

\section{Evidencia de Validez de la Escala de Dificultades en la Regulación Emocional - DERS}

Resumen: La regulación emocional es una construcción reciente y hay pocos instrumentos adaptados en Brasil capaces de medirla. Este estudio tuvo como objetivo encontrar evidencia de validez de contenido, consistencia interna y confiabilidad de la Escala de Dificultades en la Regulación Emocional (DERS) para el contexto brasileño. Los participantes fueron 402 adultos (78.1\% mujeres), con edades comprendidas entre 18 y 71 años, siendo el 86.8\% residentes de Rio Grande do Sul. Para ello, se revisó una adaptación del instrumento para facilitar la comprensión de los ítems. Para probar la estructura más apropiada para el contexto brasileño, se realizó un análisis factorial confirmatorio, comparando la estructura del instrumento original con otro validado para el contexto portugués. Los resultados mostraron que la DERS tenía buenas propiedades psicométricas, con evidencia de validez y confiabilidad del instrumento para la muestra brasileña. La estructura factorial era equivalente a la de la versión original, con seis dimensiones.

Palabras clave: regulación emocional, evaluación psicológica, psicometría

${ }^{1}$ Universidade Federal do Rio Grande do Sul, Porto Alegre-RS, Brazil

${ }^{2}$ Universidade Federal de Ciências da Saúde de Porto Alegre,

Porto Alegre-RS, Brazil

Article derived from the first author's term paper, under the supervision of the second and guidance of the third and fourth authors, defended in 2017, in the psychology course at the Universidade Federal de Ciências da Saúde de Porto Alegre.

Corresponding author: Bruna Mattos Machado. Universidade Federal de Ciências da Saúde de Porto Alegre. Rua Sarmento Leite, 245, Porto Alegre, RS, Brazil. CEP 90.050-170. E-mail: brunamm1@yahoo.com.br
Emotion regulation is associated with the ability to modulate emotional experience (Heiy \& Cheavens, 2014). It involves the individual's ability to handle the intensity and duration of emotions, and is related to change in experience rather than elimination of emotions considered unpleasant. The lack or struggle in any of these skills may suggest difficulties in emotion regulation (Gratz \& Roemer, 2004). Individuals with good emotion regulation skills tend to respond adequately to ongoing situations and demands, 
using socially desirable responses corresponding to that specific context (English, Lee, John, \& Gross, 2017). On the other hand, individuals with difficulties in regulating their emotions react inappropriately and in a decontextualised manner (Kim \& Cicchetti, 2010), presenting, for example, aggressive behaviors (Roberton, Daffern, \& Bucks, 2014).

There are several emotion regulation strategies, and many can be used simultaneously. For didactic purposes, Gross (2014) differentiates and categorizes them into five: situation selection; situation modification; attention deployment; cognitive change; and response modulation. Moreover, Nelis, Quoidbach, Hansenne and Mikolajczak (2011) propose two basic emotion regulatory processes: down-regulation and up-regulation. The first intends to reduce the unpleasant consequences of 'negative' emotions whereas the second attempts to enhance the effects of 'positive' emotions. Thus, the authors propose 16 regulation strategies for positive and negative emotions, half of which are considered functional and the remaining dysfunctional.

Emotion regulation has aroused the interest of researchers, especially in the last three decades (Gross, 2015; Naragon-Gainey, McMahon, \& Chacko, 2017). This occurs because researchers recognize the importance of this concept in understanding emotion and its impact on attention, problem solving, individual well-being (Santana \& Gondim, 2016) and interpersonal relationships (Cole, Martin, \& Dennis, 2004). Several studies relate psychopathologies to difficulties in emotions regulation, as mood and anxiety disorders (Joormann \& Siemer, 2014; Klemanski, Curtiss, McLaughlin, \& Nolen-Hoeksema, 2016), as well as personality disorders, especially the Borderline Personality Disorder (Fletcher, Parker, Bayes, Paterson, \& McClure, 2014; Silvers et al., 2016).

The increasing interest in the theme encouraged the development of instruments to measure it, some of which were adapted to the Brazilian context. Among them are The Emotion Regulation Questionnaire (ERQ), by Gross and John (2003), adapted as Emotion Regulation Questionnaire by Boian, Soares and Silva (2009) and validated by Batistoni, Ordonez, Silva, Nascimento and Cachioni (2013); the Emotion Regulation Profile (ERP) by Nelis et al. (2011), validated in Brazil by Gondim et al. (2015); and the Difficulties in Emotion Regulation Scale (DERS), developed by Gratz and Roemer (2004) and adapted for Brazil by Boeckel (2013).

Boeckel (2013) has adapted and used the instrument together with other materials to identify the impacts of domestic violence in emotion recognition and cortisol levels in mothers and children, within the maternal bonding and mothers' emotion dysregulation. The instrument assessed correlations between the degree of maternal bonding and difficulties in mothers' emotion regulation, resulting in the negative correlation of the variables. Despite important results of this study, the used version of the instrument still lacks evidence of validity, which is the purpose of our study.

The ERQ (Gross \& John, 2003) aims to examine individual differences in the systematic use of emotion regulation strategies. This is a seven-point Likert scale consisted of 10 items regarding two processes of emotion regulation (six items assemble the "cognitive change" factor and four the "emotion suppression"). To use it on the adult Brazilian population, Boian et al. (2009) performed a linguistic adaptation of the material, and Batistoni et al. (2013) examined psychometric indicators within an elderly population. The two factors (Cognitive Reassessment; Emotional Suppression) explained $50.1 \%$ of the variance, and the internal consistency index was above 0.60 .

The Emotion Regulation Profile - ERP (Nelis et al., 2011) measures emotion regulation regarding the social context characteristics and their impact on choosing strategies to deal with emotions. The ERP consists of 15 scenarios, nine of which describe situations that tend to generate negative emotional responses and six that elicit positive emotions. This study (Gondim et al., 2015) confirmed ERF validity in its complete and reduced version, within a sample of Brazilian participants. The result of principal components analysis corroborated the bifactorial structure identified in the original measurement study, that is: one regulation factor for negative emotions (down-regulation) and one for positive emotions (up-regulation). Results indicated that the average factor loadings were between 0.55 (negative emotions) and 0.69 (positive emotions), explaining $40.5 \%$ of the variance. Each factor presented satisfactory internal consistency (both with $\alpha=0.60$ ).

Most of instruments found in the Brazilian reality prioritized the evaluation of just a few emotion regulation strategies. Therefore, the Difficulties in Emotion Regulation Scale - DERS (Gratz \& Roemer, 2004), for being multidimensional, has a different proposal than the others. It assesses six dimensions of emotion dysregulation: nonacceptance of negative emotions (Non-Acceptance), inability to engage in goal-oriented behavior when experiencing negative emotions (Goals), difficulties in controlling impulsive behavior when experiencing negative emotions (Impulse), limited access to emotion regulation strategies perceived as effective (Strategies), lack of emotional awareness (Awareness) and lack of emotional clarity (Clarity). Gratz and Roemer (2004), after an extensive research, sought to integrate characteristics of emotion regulation and dysregulation. According to them, emotion regulation comprises several aspects, such as awareness and understanding of what one feels, emotion acceptance, and control of impulsive behavior, compliant with individual goals. Moreover, emotion regulation encompasses strategies and flexibility in choosing them in the face of unpleasant situations (Gratz \& Roemer, 2004).

The DERS contains 36 items on a five-point Likert scale ranging from 1 (never) to 5 (always). In the original version (Gratz \& Roemer, 2004), the six factors represented $55.68 \%$ of the total variance of the measured variables, with high internal consistency $(\alpha=0.93)$. The instrument was adapted for different countries (Coutinho, Ribeiro, Ferreirinha, \& Dias, 2010; Giromini, Velotti, Campora, Bonalume, \& Zavattini, 2012; Kökönyei, Urbán, Reinhardt, 
Józan, \& Demetrovics, 2014), presenting good psychometric results. In Brazil, studies performed by Miguel, Giromini, Colombarolli, Zuanazzi and Zennaro (2017) and Cancian, Souza, Silva, Machado and Oliveira (2019) found good internal consistency $(\alpha=0.94)$ and adequate convergent validity. Regarding the factorial structure, the study presented evidences that reinforced the six-factor structure.

To search for evidence of validity of the instrument Portuguese version, the authors (Coutinho et al., 2010) opted for an exploratory factor analysis, finding similar results to the original version that presented good degrees of internal consistency and external validity. The six dimensions of the original instrument were maintained, but two factors were included. Whereas item 23 pertains to the 'Strategies' factor in its Portuguese version, in the original it is within 'No Acceptance'. Conversely, item 30 was inserted in the 'Non-acceptance' factor in the Portuguese version, while in the original it is within 'Strategies'. Coutinho et al. (2010) performed an analysis with a clinical sample composed by 115 subjects, and found higher levels of emotion regulation difficulties in individuals with psychopathology than in individuals without clinical diagnosis.

Thus, acknowledging the instrument multidimensional structure, which includes the different aspects of the construct, and in view of the scarcity of validated tests to assess difficulties in emotion regulation in Brazil, DERS is relevant for diagnostic investigation and scientific research on the matter. This study aimed to find evidences of content validity, internal consistency and reliability of the Difficulties in Emotion Regulation Scale (DERS) for the Brazilian context. Thus, we performed a comparative study between the structure of the North American instrument (Gratz \& Roemer, 2004) and its Portuguese version (Coutinho et al., 2010). We reviewed Boeckel's (2013) proposed adaptation and replaced some terms by others more approachable and easier to understand.

\section{Method}

\section{Participants}

The participants were 402 adults (78.1\% women) aged between 18 and 71 years $(M=31.63 ; S D=11.56)$. The convenience sample was generated by the disclosure in social networks and universities institutional emails. As for location, $86.8 \%$ of the participants resided in the state of Rio Grande do Sul, whereas the remaining were residents of Santa Catarina, Paraná, Mato Grosso do Sul, Federal District, São Paulo, Rio de Janeiro, Minas Gerais, Sergipe, Bahia and Rio Grande do Norte. Regarding educational level, 95.8\% of the participants had at least incomplete higher education, of which: $35.6 \%$ had incomplete higher education; $27.1 \%$ completed higher education; $33.1 \%$ attended graduation, and $4.2 \%$ completed high school.

As to marital status, $39.6 \%$ of participants were single, $36.3 \%$ were in a stable relationship, $21.1 \%$ married, $1.8 \%$ widowed and $1.5 \%$ divorced. The number of participants in the study was defined by the number of items in the instrument in a 5: 1 ratio; the sample had at least five times the number of items of the instrument (Hair, Black, Babin, Anderson, \& Tatham, 2009).

\section{Instruments}

The following instruments were used in this study:

Sociodemographic questionnaire. The questionnaire consisted of six closed questions that enabled the collection of subjects' socio-demographic data.

Difficulties in Emotion Regulation Scale - DERS. This scale was developed in the United States by Gratz and Roemer (2004), and adapted and validated to Portugal by Coutinho et al. (2010) and to Brazil by Boeckel (2013). As aforementioned, both the North American and Portuguese scales presented good psychometric indices. The instrument is composed by 36 items divided into six dimensions.

The 'Impulses' factor is formed by items reflecting the individual's difficulties in controlling their own behaviors in moments of anguish, for example: "When I'm upset, I lose control over my behaviors". The 'Non-Acceptance' factor contains items characterizing the tendency to react in denial in face of unpleasant emotions, for example: "When I'm upset, I become angry with myself for feeling that way". 'Awareness' is represented by items assessing a tendency to pay attention and recognize emotions, for example: "I am attentive to my feelings.".

'Goals' assesses difficulties in concentrating and accomplishing tasks during emotional distress, for example: "When I'm upset, I have difficulty concentrating". The set of items that reflect the belief that there is little to be done to regulate emotions effectively make up the "Strategies" factor, for example: "When I am not well, I believe that I will end up feeling depressed". Finally, 'Clarity' is composed of items that assess the extent to which individuals know and are clear about the emotions they experience, for example: "I am confused about how I feel".

\section{Procedure}

This is a quantitative and cross-sectional study. This research used the linguistic adaptation for Brazilian Portuguese developed by Boeckel (2013). We also reviewed the adaptation proposed by the author to facilitate the understanding of the items, as we considered some terms difficult. Therefore, we produced the final version in Portuguese using the original scale in English (Gratz \& Roemer, 2004) and the adapted version to Portugal (Coutinho et al., 2010). The adaptation process consisted of: (1) translation of the instrument into the target language by two independent translators; (2) synthesis of the translated versions; (3) synthesis evaluation by expert judges; (4) instrument evaluation by the target audience. These steps compose the Borsa, Damásio and Bandeira's adaptation proposal (2012). For adapting terms of a scale previously 
adapted to Brazil, we deemed the aforementioned steps enough to preserve the essence of the instrument's items, considering cultural and linguistic issues (Borsa et al., 2012).

Thus, two independent bilingual translators translated the items for the Portuguese version (Coutinho et al., 2010). Then, we synthesized these items and the version adapted by Boeckel (2013). Five expert judges evaluated the resulting scale. We considered the suggestions made by them and sent a new version of the instrument to 10 subjects, representing the target audience, which evaluated each item. We adapted the material and obtained the final version of the instrument for application.

Data collection. The participants responded to the questionnaires, available on an online platform. First, the participant read a rapport presenting the research and the procedures, and explaining the voluntary nature of participation. At this point the informed consent form was provided. Participant then completed the questionnaire with personal and socio-demographic data, to characterize the sample. At last, DERS Brazilian version was provided to the participants. The time taken to complete the instrument was relatively short, about 15 minutes for most participants.

Data Analysis. We performed a confirmatory factor analysis to assess whether DERS factorial structure would replicate in the national context, specifying the models proposed by Coutinho et al. (2010) and Gratz and Roemer (2004). The polychoric correlations matrix of the data was submitted to the Robust Weighted Least Squares - RWLS estimation method (Rosseel, 2012). We chose this method for not assuming normality in the distribution of responses to items, although it is necessary and offers more accurate and less biased estimates for the categorical indicators of ordinal level (Flora \& Curran, 2004).

The quality of the model was assessed using the significance level of the chi-square index and degrees of freedom, the CFI (Comparative Fit Index), TLI (TuckerLewis Index), RMSEA (Root Mean Square Error of Approximation) and SRMR (Standardized Root Mean Square Residual). RMSEA and SRMR values lower than 0.05 indicate a good fit, whereas lower than 0.08 indicate an acceptable fit. CFI and TLI above 0.95 suggest excellent fit, whereas above 0.90 indicate satisfactory fit $(\mathrm{Hu} \&$ Bentler, 1999)which includes using the maximum likelihood (ML. We used the criterion suggested by Cheung and Rensvold (2001) to compare the USA (Gratz \& Roemer, 2004) model with the Portugal (Coutinho et al., 2010) model. This criterion deems the chi-square index to be significant due to the sample size. Thus, CFI and RMSEA were considered. According to the criterion, a change in CFI lower than 0.01 and a in RMSEA lower than 0.015 implies that a more parsimonious model is preferred.

The internal consistency of the scale was assessed using the reliability evaluation by Cronbach's alpha. Although, as the alpha tends to be biased in the presence of data with different discrimination (varying factor loadings) and multidimensionality, McDonald's Omega was also reported (Dunn, Baguley, \& Brunsden, 2014). For them both, coefficients were interpreted as follows: $<0.60=$ inadequate; from 0.60 to $0.69=$ marginal reliability; from 0.70 to $0.79=$ acceptable; from 0.80 to 0.89 good; and 0.90 or above $=$ excellent (Hair et al., 2009). We performed the analysis in the $\mathrm{R}$ statistical computing environment (R Core Team, 2017) and used the package lavaan, especially for confirmatory factor analysis (Rosseel, 2012).

\section{Ethical Considerations}

The study complies with the provisions of the Resolution No. 466/12 of the National Health Council, and was submitted to and approved by the Research Ethics Committee of the Universidade Federal de Ciências da Saúde de Porto Alegre (UFCSPA) (CAAE: 67674717.3.0000.5345). All participants voluntarily accepted to participate in the research.

\section{Results}

The results indicate that the KMO index of sampling adequacy was 0.94 and Bartlett's Test of Sphericity was significant $(p<0.001)$. Therefore, we proceeded to the confirmatory factor analysis. Both proposed models obtained acceptable fit indices, with little practical difference between them (Table 1). Although Coutinho et al. (2010) model presented psychometric parameters similar to the American model, the last one was was slightly favorable in terms of fit ( $\mathrm{RMESEA}=0.07$, instead of 0.08 in the Portuguese model). Thus, the American model parameters are reported.

Table 1

Fit indexes of confirmatory factor models

\begin{tabular}{lccccc}
\hline $\begin{array}{l}\text { Confirmatory } \\
\text { Model }\end{array}$ & $\chi^{2}(\mathrm{gl})$ & CFI & TLI & SRMR & RMSEA \\
\hline $\begin{array}{l}\text { Gratz and } \\
\text { Roemer (2004) }\end{array}$ & $1998.33(579)$ & 0.98 & 0.98 & 0.07 & 0.07 \\
$\begin{array}{l}\text { Coutinho et al. } \\
(2010)\end{array}$ & $1957.68(579)$ & 0.98 & 0.98 & 0.07 & 0.08 \\
\hline
\end{tabular}

Note. $\mathrm{df}=$ degrees of freedom; CFI = Comparative Fit Index; TLI $=$ Tucker-Lewis Index; RMSEA $=$ Root Mean Square Error of Approximation; SRMR = Standardized Root Mean Square Residual.

Regarding Gratz and Roemer (2004) model, all items presented significant factor loadings, ranging from 0.41 to 0.91 , and with an average of 0.77 . Communalities ranged between 0.16 and 0.95 , with an average of 0.63 (Table 2). In view of the adequacy of test results, no changes were proposed. 
Table 2

Factor loading, communalities (h2) regarding Gratz and Roemer (2004) confirmatory factorial model

\begin{tabular}{|c|c|c|c|c|c|c|c|}
\hline Items & Factor 1 & Factor 2 & Factor 3 & Factor 4 & Factor 5 & Factor 6 & $\mathrm{~h}^{2}$ \\
\hline 32. When I'm upset, I lose control over my behavior. & 0.91 & & & & & & 0.83 \\
\hline 14. When I'm upset, I become out of control. & 0.84 & & & & & & 0.71 \\
\hline 27. When I am upset, I have difficulty controlling my behaviors. & 0.87 & & & & & & 0.75 \\
\hline 19. When I'm not well, I feel out of control. & 0.91 & & & & & & 0.83 \\
\hline $\begin{array}{l}\text { 24. When I'm upset, I feel like I can remain in control of my } \\
\text { behaviors (r). }\end{array}$ & 0.78 & & & & & & 0.61 \\
\hline 3. I experience my emotions as overwhelming and out of control. & 0.75 & & & & & & 0.56 \\
\hline 34. When I'm upset, I take time to figure out what I'm really feeling. (r) & & 0.64 & & & & & 0.41 \\
\hline 8. I care about what I am feeling. $(r)$ & & 0.72 & & & & & 0.52 \\
\hline $\begin{array}{l}\text { 17. When I'm upset, I believe that my feelings are valid and } \\
\text { important. (r) }\end{array}$ & & 0.57 & & & & & 0.32 \\
\hline 2. I pay attention to how I feel. (r) & & 0.81 & & & & & 0.66 \\
\hline 6. I am attentive to my feelings. (r) & & 0.90 & & & & & 0.82 \\
\hline 10. When I'm upset, I acknowledge my emotions. (r) & & 0.64 & & & & & 0.41 \\
\hline 11. When I'm upset, I become angry with myself for feeling that way. & & & 0.76 & & & & 0.57 \\
\hline 25. When I'm upset, I feel guilty for feeling that way. & & & 0.90 & & & & 0.81 \\
\hline 21. When I'm upset, I feel ashamed with myself for feeling that way. & & & 0.80 & & & & 0.64 \\
\hline 29. When I'm upset, I become irritated with myself for feeling that way. & & & 0.86 & & & & 0.73 \\
\hline 12. When I'm upset, I become embarrassed for feeling that way & & & 0.68 & & & & 0.47 \\
\hline 23. When I'm upset, I feel like I am weak. ${ }^{a}$ & & & 0.86 & & & & 0.73 \\
\hline 26. When I'm upset, I have difficulty concentrating. & & & & 0.86 & & & 0.72 \\
\hline 18. When I'm upset, I have difficulty focusing on other things. & & & & 0.85 & & & 0.51 \\
\hline 20. When I'm upset, I can still get things done. (r) & & & & 0.72 & & & 0.78 \\
\hline 13. When I'm upset, I have difficulty getting work done. & & & & 0.89 & & & 0.72 \\
\hline 33. When I'm upset, I have difficulty thinking about anything else. & & & & 0.85 & & & 0.48 \\
\hline 9. I am confused about how I feel. & & & & & 0.69 & & 0.34 \\
\hline 4. I have no idea how I'm feeling. & & & & & 0.59 & & 0.50 \\
\hline 7. I know exactly how I'm feeling. (r) & & & & & 0.71 & & 0.44 \\
\hline 1. I am clear about my feelings. (r) & & & & & 0.66 & & 0.48 \\
\hline 5. I have difficulty making sense out of my feelings. & & & & & 0.69 & & 0.95 \\
\hline 30. When I'm upset, I start to feel very bad about myself. ${ }^{b}$ & & & & & 0.97 & & 0.74 \\
\hline $\begin{array}{l}\text { 28. When I'm upset, I believe that there is nothing I can do to make } \\
\text { myself feel better. }\end{array}$ & & & & & & 0.82 & 0.68 \\
\hline 15. When I'm upset, I believe that I will remain that way for a long time. & & & & & & 0.85 & 0.73 \\
\hline 35. When I'm upset, it takes me a long time to feel better. & & & & & & 0.79 & 0.62 \\
\hline $\begin{array}{l}\text { 22. When I'm upset, I know that I can find a way to eventually feel } \\
\text { better. (r) }\end{array}$ & & & & & & 0.81 & 0.65 \\
\hline 16. When I'm upset, I believe that I'll end up feeling very depressed. & & & & & & 0.90 & 0.81 \\
\hline 31. When I'm upset, I believe that wallowing in it is all I can do. & & & & & & 0.41 & 0.16 \\
\hline 36. When I'm upset, my emotions feel overwhelming. & & & & & & 0.84 & 0.71 \\
\hline
\end{tabular}

Note. ${ }^{\text {a }}$ Item No. 23 was part of factor 6 in the Portuguese instrument; ${ }^{\mathrm{b}}$ Item No. 30 was part of factor 3 in the Portuguese instrument; Factor loading, communalities $\left(\mathrm{h}^{2}\right)$ regarding Gratz and Roemer (2004) confirmatory factorial model. 
Cronbach's alpha and McDonald's Omega were calculated to analyze the internal consistency of the scale and its dimensions. The results were satisfactory within all subscales $(\alpha \geq 0.86$ and $\omega \geq 0.84)$. Table 3 shows the reliability values and the correlations among the scale factors.

Table 3

Cronbach's Alpha and McDonald's Omega Coefficients and Correlations between Factors

\begin{tabular}{lcccccc}
\hline & Factor & Factor & Factor & Factor & Factor & Factor \\
& 1 & 2 & 3 & 4 & 5 & 6 \\
\hline $\begin{array}{l}\text { Cronbach's } \\
\text { alpha }\end{array}$ & 0.93 & 0.86 & 0.91 & 0.91 & 0.86 & 0.91 \\
Coefficient & & & & & & \\
McDonald's & 0.91 & 0.84 & 0.91 & 0.89 & 0.84 & 0.89 \\
Omega & & & & & & \\
Coefficient & & & & & & \\
Correlations & & & & & & \\
Factor 1 & & & & & & \\
Factor 2 & 0.26 & & & & & \\
Factor 3 & 0.65 & 0.30 & & & & \\
Factor 4 & 0.73 & 0.17 & 0.55 & & & \\
Factor 5 & 0.63 & 0.70 & 0.78 & 0.56 & & \\
Factor 6 & 0.79 & 0.30 & 0.74 & 0.72 & 0.71 & \\
\hline
\end{tabular}

The first factor refers to 'Impulse Control Difficulties' (Impulses) and is composed of six items. The second factor is also composed of six items and refers to the 'Lack of Emotional Awareness' (Awareness). The third factor has six items related to 'Non-acceptance of Emotional Responses' (Non-acceptance). The fourth factor refers to 'Difficulties Engaging in Goal-Directed Behavior' (Goals), with five items. The fifth factor refers to 'Lack of Emotional Clarity' (Clarity), presenting six items; and the sixth factor addresses 'Limited Access to Emotion Regulation Strategies' (Strategies), with seven items.

\section{Discussion}

The results of the study show that DERS presented good psychometric properties. The factor analysis confirmed the results on the North American model, with adjustment of six dimensions of the scale. The analysis of the Portuguese version found seven factors with eigenvalues above 1 . However, the Portuguese researchers concluded that six factors would be ideal for the instrument, and maintained this structure. Cronbach's alpha ( $\alpha \geq 0.82$ for each subscale) also showed similar results to the North American $(\alpha>0.80$ for each subscale) and Portuguese ( $\alpha \geq 0.75$ for each subscale) studies. The findings within the Brazilian sample reinforce the multidimensional conceptualization of the construct and verify that the instrument presents a consistent factorial structure, similar to the original. This study improved the scale and the understanding of the application of different models to investigate difficulties in emotion regulation.

Items distribution was more adequate and matched the North American scale. When relating it to the Portuguese version of the instrument, we disagreed regarding two items. In the Portuguese version, Item No. 23 "When I am upset, I feel like I am weak" pertains to 'Strategies'; in this study, the item remains in the 'No Acceptance' factor, similarly to the original instrument. Item No. 30 "When I'm upset, I start to feel very bad about myself" also differed from the Portuguese scale. Whereas in this study it was in the 'Strategies' factor, in the Portuguese instrument it was adapted to 'NonAcceptance'. Thus, besides adapting to the statistical criteria, the Brazilian instrument was theoretically correspondent to that developed by Gratz and Roemer (2004).

This study sample was predominantly formed by female (78\%) and residents of Rio Grande do Sul, presenting a limitation. The instrument is suitable for populations with a higher educational level $(95.8 \%$ of the sample had between incomplete higher education and graduate studies). The results suggest the need for further investigations that enable the validation of the instrument within more diverse samples for the Brazilian population, including a larger number of male participants, of low educational level and residents of other Brazilian regions.

We concluded that the Brazilian version of DERS presented construct validity, being applicable to the Brazilian population. It assists researches that require construct measurement. We suggest further studies with samples composed by individuals clinically diagnoses of psychiatric disorders, corroborating researches regarding difficulties in emotion regulation within psychiatric diseases. The instrument could support clinical evaluations and contribute to the identification of areas of greatest difficulty for the patient, helping to establish defined goals and contributing to psychotherapeutic work.

\section{References}

Batistoni, S. S. T., Ordonez, T. N., Silva, T. B. L., Nascimento, P. P. P., \& Cachioni, M. (2013). Emotional Regulation Questionnaire (ERQ): Psychometric indicators and affective relations in an elderly sample. Psicologia: Reflexão e Crítica, 26(1), 10-18. doi:10.1590/S010279722013000100002

Boeckel, M. G. (2013). Ambientes familiares tóxicos: Impactos da violência conjugal na vinculação entre mães e filhos, no reconhecimento de emoções e nos níveis de cortisol [Toxic family environments: Impacts of conjugal violence in the bonding between mothers and children, recognition of emotions and cortisol levels] (Doctoral dissertation). Retrieved from http://repositorio.pucrs.br/ dspace/handle/10923/5482 
Boian, A. C., Soares, D. S. M., \& Silva, J. (2009). Questionário de Regulação Emocional de J. Gross \& O. John (2003): Adaptado para a população brasileira. [Emotional Regulation Questionnaire: Adapted to brazilian population] Retrieved from https://spl.stanford. edu/sites/g/files/sbiybj9361/f/portuguese_brazilian.pdf

Borsa, J. C., Damásio, B. F., \& Bandeira, D. R. (2012). Cross-cultural adaptation and validation of psychological instruments: Some considerations. Paidéia (Ribeirão Preto), 22(53), 423-432. doi:10.1590/S0103$863 \times 2012000300014$

Cancian, A. C. M., Souza, L. A. S. de, Silva, V. H. P., Machado, W. de L., \& Oliveira, M. da S. (2019). Psychometric properties of the brazilian version of the difficulties in emotion regulation scale (DERS). Trends in Psychiatry and Psychotherapy, 41(1), 18-26. doi: 10.1590/2237-6089-2017-0128

Cheung, G. W., \& Rensvold, R. B. (2001). The effects of model parsimony and sampling error on the fit of structural equation models. Organizational Research Methods, 4(3), 236-264. doi:10.1177/109442810143004

Cole, P. M., Martin, S. E., \& Dennis, T. A. (2004). Emotion regulation as a scientific construct: Methodological challenges and directions for child development research. Child Development, 75(2), 317-333. doi:10.1111/j.14678624.2004.00673.x

Coutinho, J., Ribeiro, E., Ferreirinha, R., \& Dias, P. (2010). The Portuguese version of the difficulties in emotion regulation scale and its relationship with psychopathological symptoms. Revista de Psiquiatria Clínica, 37(4), 145-151. doi:10.1590/S010160832010000400001

Dunn, T. J., Baguley, T., \& Brunsden, V. (2014). From alpha to omega: A practical solution to the pervasive problem of internal consistency estimation. British Journal of Psychology, 105(3), 399-412. doi:10.1111/bjop.12046

English, T., Lee, I. A., John, O. P., \& Gross, J. J. (2017). Emotion regulation strategy selection in daily life: The role of social context and goals. Motivation and Emotion, 41(2), 230-242. doi:10.1007/s11031-0169597-z

Fletcher, K., Parker, G., Bayes, A., Paterson, A., \& McClure, G. (2014). Emotion regulation strategies in bipolar II disorder and borderline personality disorder: Differences and relationships with perceived parental style. Journal of Affective Disorders, 157, 52-59. doi:10.1016/j. jad.2014.01.001

Flora, D. B., \& Curran, P. J. (2004). An empirical evaluation of alternative methods of estimation for confirmatory factor analysis with ordinal data. Psychological Methods, 9(4), 466-491. doi:10.1037/1082-989X.9.4.466
Giromini, L., Velotti, P., Campora, G., Bonalume, L., \& Zavattini, G. C. (2012). Cultural adaptation of the difficulties in emotion regulation scale: Reliability and validity of an Italian version. Journal of Clinical Psychology, 68(9), 989-1007. doi:10.1002/jclp.21876

Gondim, S. M. G., Pereira, C. R., Hirschle, A. L. T., Palma, E. M. S., Alberton, G. D., Paranhos, J., . . Ribeiro, W. R. B. (2015). Validation evidences of a measure of personal characteristics of emotional regulation. Psicologia: Reflexão e Crítica, 28(4), 659-667. doi:10.1590/16787153.201528403

Gratz, K. L., \& Roemer, L. (2004). Multidimensional assessment of emotion regulation and dysregulation: Development, factor structure, and initial validation of the difficulties in emotion regulation scale. Journal of Psychopathology and Behavioral Assessment, 26(1), 4154. doi:10.1007/s10862-008-9102-4

Gross, J. J. (2014). Emotion regulation: Conceptual and empirical foundations. In J. J. Gross (Ed.), Handbook of emotion regulation (2nd ed., pp. 3-22). New York, NY: Guilford.

Gross, J. J. (2015). Emotion regulation: Current status and future prospects. Psychological Inquiry, 26(1), 1-26. doi: 10.1080/1047840X.2014.940781

Gross, J. J., \& John, O. P. (2003). Individual differences in two emotion regulation processes: Implication for affect, relationships, and well-being. Journal of Personality and Social Psychology, 85(2), 342-362. doi:10.1037/00223514.85.2.348

Hair, J. J., Jr., Black, C. W., Babin, B. J., Anderson, R. E., \& Tatham, R. L. (2009). Análise multivariada de dados [Multivariate data analysis] (A. S. Sant'Anna, Trans., 6th ed.). Porto Alegre, RS: Bookman.

Heiy, J. E., \& Cheavens, J. S. (2014). Back to basics: A naturalistic assessment of the experience and regulation of emotion. Emotion, 14(5), 878-891. doi:10.1037/ a0037231

Hu, L.-T., \& Bentler, P. M. (1999). Cutoff criteria for fit indexes in covariance structure analysis: Conventional criteria versus new alternatives. Structural Equation Modeling, 6(1), 1-55. doi:10.1080/10705519909540118

Joormann, J., \& Siemer, M. (2014). Emotion regulation in mood disorders. In J. J. Gross (Ed.), Handbook of emotion regulation (2nd ed., pp. 413-427). New York, NY: Guilford.

Kim, J., \& Cicchetti, D. (2010). Longitudinal pathways linking child maltreatment, emotion regulation, peer relations, and psychopathology. Journal of Child Psychology and Psychiatry, 51(6), 706-716. doi:10.1111/ j.1469-7610.2009.02202.x 
Klemanski, D. H., Curtiss, J., McLaughlin, K. A., \& NolenHoeksema, S. (2017). Emotion regulation and the transdiagnostic role of repetitive negative thinking in adolescents with social anxiety and depression. Cognitive Therapy and Research, 41(2), 206-219. doi:10.1007/ s10608-016-9817-6

Kökönyei, G., Urbán, R., Reinhardt, M., Józan, A., \& Demetrovics, Z. (2014). The difficulties in emotion regulation scale: Factor structure in chronic pain patients. Journal of Clinical Psychology, 70(6), 589-600. doi:10.1002/jclp.22036

Miguel, F. K., Giromini, L., Colombarolli, M. S., Zuanazzi, A. C., Zennaro, A. (2017). A Brazilian investigation of the 36- and 16-item Difficulties in Emotion Regulation Scales. Journal of Clinical Psycholy, 73(9), 1146-1159. doi: $10.1002 /$ jclp. 22404

Naragon-Gainey, K. N., McMahon, T. P., \& Chacko, T. P. (2017). The structure of common emotion regulation strategies: A meta-analytic examination. Psychological Bulletin, 143(4), 384-427. doi:10.1037/bul0000093

Nelis, D., Quoidbach, J., Hansenne, M., \& Mikolajczak, M. (2011). Measuring individual differences in emotion regulation: The emotion regulation profilerevised (ERP-R). Psychologica Belgica, 51(1), 49-91. doi:10.5334/pb-51-1-49

R Core Team. (2017). The $R$ Project for Statistical Computing. Vienna, Austria: R Foundation. Retrieved from http://www.R-project.org/

Roberton, T., Daffern, M., \& Bucks, R. S. (2014). Maladaptive emotion regulation and aggression in adult offenders. Psychology, Crime \& Law, 20(10), 933-954. doi:10.1080/1068316X.2014.893333

Rosseel, Y. (2012). lavaan: An R package for structural equation modeling. Journal of Statistical Software, 48(2), 1-36. doi:10.18637/jss.v048.i02

Santana, V. S., \& Gondim, S. M. G. (2016). Regulação emocional, bem-estar psicológico e bem-estar subjetivo [Emotion regulation, psychological well-being and subjective well-being]. Estudos de Psicologia (Natal), 21(1), 58-68. doi:10.5935/1678-4669.20160007

Silvers, J. A., Hubbard, A. D., Biggs, E., Shu, J., Fertuck, E., Chaudhury, S., ... Stanley, B. (2016). Affective lability and difficulties with regulation are differentially associated with amygdala and prefrontal response in women with borderline personality disorder. Psychiatry Research. Neuroimaging, 254, 74-82. doi:10.1016/j. pscychresns.2016.06.009
Bruna Mattos Machado is a doctoral student of the Universidade Federal do Rio Grande do Sul, Porto AlegreRS, Brazil.

Léia Gonçalves Gurgel is a invited researcher at the Universidade Federal de Ciências da Saúde de Porto Alegre, Porto Alegre-RS, Brazil.

Mariana Gonçalves Boeckel is a Professor at the Universidade Federal de Ciências da Saúde de Porto Alegre, Porto AlegreRS, Brazil.

Caroline Tozzi Reppold is a Professor at the Universidade Federal de Ciências da Saúde de Porto Alegre, Porto AlegreRS, Brazil.

Authors' Contribution:

All authors made substantial contributions to the conception and design of this study, to data analysis and interpretation, and to the manuscript revision and approval of the final version. All the authors assume public responsibility for content of the manuscript.

Received: Apr. 11, 2018

1st Revision: Jul. 31, 2018

2nd Revision: Oct. 24, 2018

3rd Revision: Dec. 16, 2018

Approved: Dec. 19, 2018

How to cite this article:

Machado, B. M., Gurgel, L. G., Boeckel, M. G., \& Reppold, C. T. (2020). Evidences of validity of the Difficulties in Emotion Regulation Scale - DERS. Paidéia (Ribeirão Preto), 30, e3017.doi:http://dx.doi.org/10.1590/1982-4327e3017 